IRA-International Journal of Management \& Social Sciences

ISSN 2455-2267; Vol.06, Issue 01 (2017)

Pg. no. 109-117

Institute of Research Advances

http://research-advances.org/index.php/RAJMSS

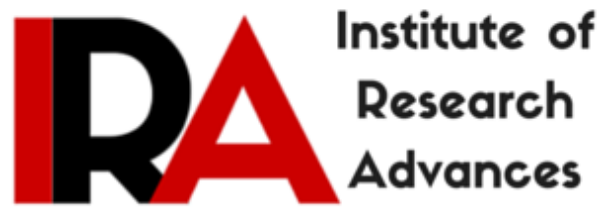

\title{
A Comparative Study of Gender Roles in Tea Sector in Embu and Murang'a Counties, Kenya: A Case Study of Smallholder Tea Farmers
}

\author{
Samson M. Makone ${ }^{1}$, Naphis M. Bitange ${ }^{2}$, Nathan O. Soire ${ }^{3}$, Eveline A. Odero ${ }^{4}$ \\ ${ }^{1}$ Faculty of Agriculture and Natural Resources Management, Kisii University, Kenya. \\ ${ }^{2}$ Kenya Tea Development Agency (KTDA), Kenya. \\ ${ }^{3}$ Department of Agriculture, Livestock and Fisheries, Kisii County Government, Kenya. \\ ${ }^{4}$ Kenya Tea Development Agency (KTDA), Kenya.
}

Type of Review: Peer Reviewed.

DOI: http://dx.doi.org/10.21013/jmss.v6.n1.p15

How to cite this paper:
Makone, S., Bitange, N., Soire, N., \& Odero, E. (2017). A Comparative Study of
Gender Roles in Tea Sector in Embu and Murang'a Counties, Kenya: A Case Study of
Smallholder Tea Farmers. IRA-International Journal of Management \& Social Sciences
(ISSN 2455-2267), 6(1), 109-117. doi:http://dx.doi.org/10.21013/jmss.v6.n1.p15

(C) Institute of Research Advances

(cc) EY-NC

This work is licensed under a Creative Commons Attribution-Non Commercial 4.0 International License subject to proper citation to the publication source of the work.

Disclaimer: The scholarly papers as reviewed and published by the Institute of Research Advances (IRA) are the views and opinions of their respective authors and are not the views or opinions of the IRA. The IRA disclaims of any harm or loss caused due to the published content to any party. 


\section{ABSTRACT}

Men and women perform different roles within the household and in agricultural sector. However, women's roles are more strenuous and more pronounced and they work extra hours in providing the much needed labour on the tea farms than the men counterpart. But in spite of women's much involvement in agricultural sector, they undergo discrimination in all aspects not only related to land ownership but also kept out when it comes to control and access to the benefits accrued from tea farming. This study therefore sought to determine gender roles in tea production in Embu and Murang'a counties and also to assess the accessibility and control over the benefits accrued from tea farming by gender. Stratified random sampling; simple random sampling and Purposive sampling techniques were used to sample 276 respondents from estimated target population of 18,000 tea growers from the two counties under study. The study established that women perform more roles in tea plantation than their male counterparts. The findings clearly demonstrated that the most tedious and difficult roles that took long hours to accomplish were assigned to the women for instance, the plucking of tea, taking green leaves to the buying centre and collecting/receiving pay slips from the factory or buying centre was majorly done by the women but it's men who goes to the bank to earn bonus and monthly payments for the work didn't participate and also attending annual general meetings (AGMs) or any meetings at the factory or buying centre and even organized educational forums and surveys since they knew that at the end of it they would either receive certificate of participation and more importantly sitting allowance. The finding further revealed that, men were assigned themselves roles that lighter duties that might require bit of skills such as pruning of tea bushes and nursery establishment. On the other hand women are unable to attend the forums or meetings because of numerous roles waiting for them ranging from household chores to agricultural production. Although conflicts have been in arise over the control of proceeds of tea sales because men receive the benefits and women who worked for them do not seem to benefit much, this gender discrimination had negatively affected tea production and by extension resulted in decline of tea yields and neglected tea bush. This study recommends that Kenya tea development agency to increase its sensitization forums and conducts regular workshops to educate the tea growers on gender balance in regards to distribution of proceeds from tea sales, access to and control over tea benefits. This could not only help to empower and motivate women but also demystify the gender stereotypes that men have about women and therefore eliminate gender discrimination in tea growing communities.

\section{INTRODUCTION}

Kenya is ranked one of the leading tea producing countries globally and about $90 \%$ of its population lives in the rural areas. In addition, the tea sector in Kenya is largely liberalized and is comprised of the small scale tea growers contributing about $70 \%$ of total tea production and large tea estates which mostly owned by the multinationals. Nyangito, (2001) described smallholder tea growers as those whose tea bushes occupy less than eight hectares of land and majority of these farmers fall under Kenya Tea Development Agency (KTDA) while, the large tea estates on the other hand constitutes mainly large-scale tea plantations that usually operate under Kenya Tea Growers Association (KTGA). The main mandate of the Kenya Tea Development Agency (KTDA) is to provide a link between the farmers and Tea Research Foundation of Kenya (TRFK) through the agency's elaborate extension system; they also disseminate recommended agricultural practices to the farmers from and within the small holder sub-sector.

In Africa, women work in different ways however, their roles seems very substantial especially in agricultural production. Women provide atleast half of the workforce in Sub-Sahara Africa even though they are denied equal access to and control over the resources (Kibere et al, 2013). Their contribution in agricultural sector is seen insignificant and thus looked down upon (ILO, 2002). When it comes to decision making, the women usually have no voice or little and their needs and constraints lack influence to acquaint public policy choices and priorities (World Bank, 2001). Extreme gender biasness in control over and access to benefits accrued from agricultural sector and land ownership, is a major impediments to women's economic growth (Cornhiel, 2008). Women in Africa are very crucial as far as agriculture is 
concern and their initiatives to improve the agricultural productivity cannot be looked down upon since most communities depend on agriculture for their livelihoods UNDP/IMF, 2007).

Gender is socially formed and it is mostly used to govern and organize the processes of production, reproduction, distribution and consumption (Kibere et al., 2013). According to World Bank, (2000), Gender imbalances sometimes many make individuals to encounter multiple deprivations because of the interaction of social and economic processes. It is imperative to believe the state under which men and women gain control over and access to yielding resources due to deep-rooted socio-economic factors that form the basis of farming (Overholt, 2008); it as directly related with the membership in social groups whereas the nature of relations between the members influence patterns of land ownership and production (UNDP, 2001). It is therefore essential to establish the challenges women farmers undergo in the society in the area of control over and access to tea benefits (Kibere et al., (2013)

To motivate women, their rights should be protected so that they fully enjoy all rights that are also being enjoyed by men counterparts (AU, 2003). This was supported by the African Union Protocol on women with the expectation that all agriculture stakeholders and other sectors will now and in the future make use of gender lenses to guide them in asking the following questions such as: who produces, who reproduces, who earns, who controls, who accesses, who owns, who benefits, who decides and who loses?;in so doing we will able to get gender inclusivity without biasness in all work places and more importantly in agricultural sectors. Therefore, the tremendous contributions of the women in agriculture more precisely in tea farming cannot be ignored (Kibere et al., 2013). Sustainable rural development and productive agriculture cannot be realized without the emphasis of women's significant roles they play in determining and assuring the well-being of the whole household. It is important to ensure that all the tea farming potential actors are provided with the necessary support to control and access the benefits accrued from the farming so that they too enjoy better lives and sustainable livelihoods (Overholt, 1999).

\section{MATERIALS AND METHODS}

\section{Research Design}

This study employed descriptive research design. According to Doyle (2004), a descriptive study refers to a body of techniques for collecting data from individuals to a set of prepared questions. Surveys are important in research and have been found to be useful in describing a population under study in an attempt to explain why the situation is in the way it is (Kothari, 2004). They are cost effective and exploratory in nature thus enabling one to make inferences into levels of cause and effect. Because of its nature in collection both qualitative and quantitative data without involving manipulation of treatments, this survey was appropriate design to use in this study. A survey was employed to assess gender roles among the small scale farmers in Tea Sector in Embu and Murang'a Counties, Kenya with a view of providing necessary information regarding the set objectives. 


\section{The Study Sites}

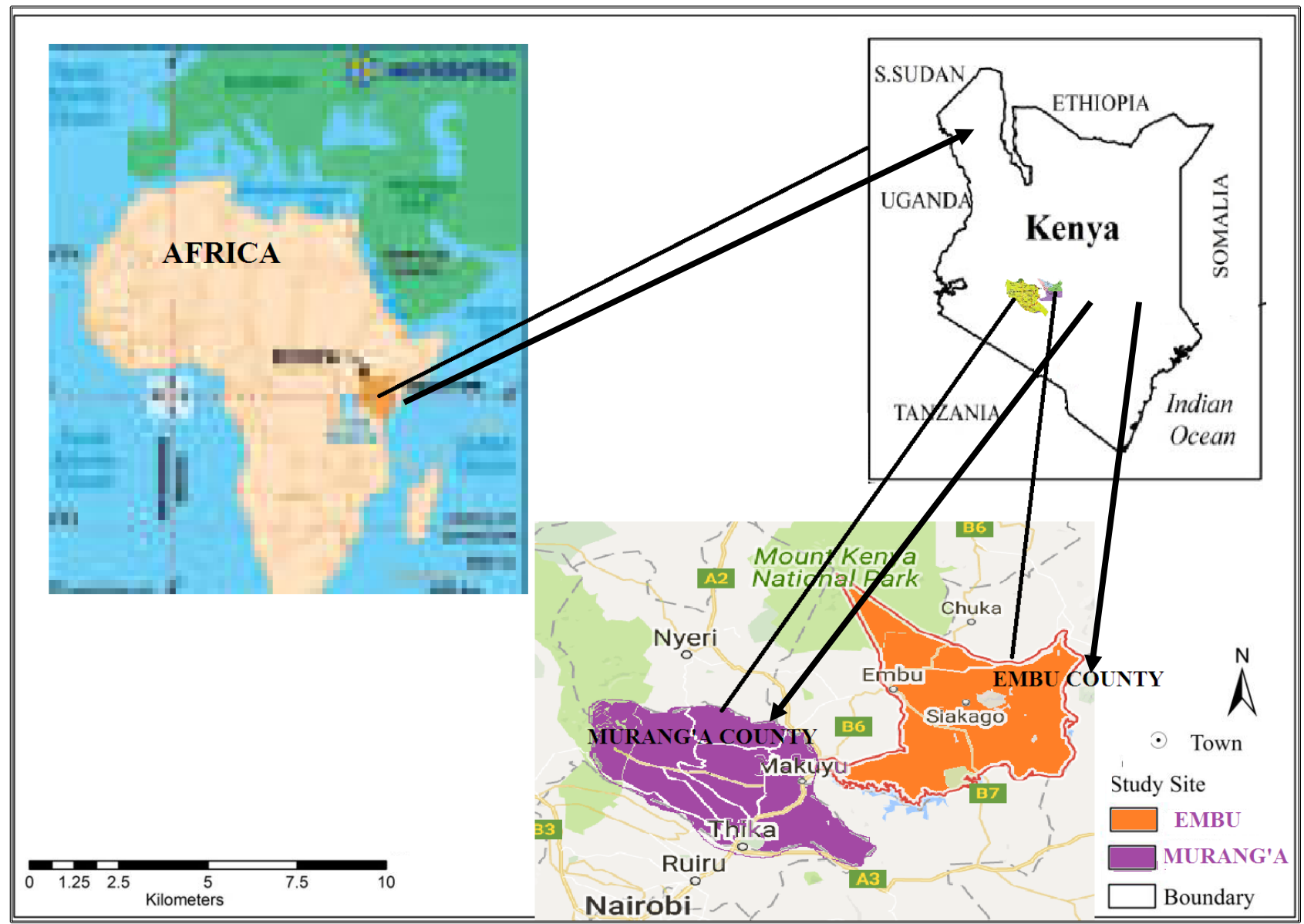

\section{Sample Size and Sampling Technique}

The study employed multiple sampling procedures to determine the sample size which includes: Stratified random sampling, simple random sampling and purposive sampling techniques. Stratified random sampling was adopted since the three categories of employees (management, employees and tea farmers) selected from the six strata/factories ( 3 from Embu and 3 from Murang'a) were relatively heterogeneous. The three levels of employees represent three strata. Within each stratum, the respondents were required to be homogenous. Moreover, simple random sampling and purposive sampling techniques was conducted amongst the respondents drawn from the six selected stratum/factories.

The factory management official were purposively selected from each stratum on the basis of who meets the purpose of the study at its best while, factory employees and tea farmers was subjected to simple random sampling using the following formulae suggested by Fisher et al. (2003), to determine the sample size. The formula is:

$$
n=\frac{Z^{2} p q}{\ell^{2}}
$$

\section{Where:}

$\mathrm{n} \quad=\quad$ Required sample size.

$\mathrm{Z}=\quad$ Confidence level, in this case $95 \%$ will be used (standard value of 1.96).

$\mathrm{p}=\quad$ Estimated proportion of households who are tea growers the in the study areas. (Approximately 80\%) and is expressed in decimal 0.8).

$\ell=\quad$ Margin of error or level of precision usually expressed in decimal, in this case 
$5 \%$ will we used (standard value of 0.05 ).

By substituting in the variables in the above formulae gives the sample of 246 respondents drawn from factory employees and tea farmers plus 30 respondents that were purposively selected from management makes a total of 276 respondents altogether. The formula was adopted since the target population was greater than 10,000 (Mugenda \& Mugenda, 2003)

Sampling Matrix

\begin{tabular}{|c|c|c|c|c|c|c|c|c|}
\hline \multirow[t]{2}{*}{$\begin{array}{l}\text { Target } \\
\text { population }\end{array}$} & $\begin{array}{l}\text { Sampling } \\
\text { design }\end{array}$ & \multicolumn{3}{|c|}{ Embu County Tea Factories } & \multicolumn{3}{|c|}{$\begin{array}{c}\text { Murang'a County Tea } \\
\text { Factories }\end{array}$} & \multirow{2}{*}{ Total } \\
\hline & $\begin{array}{l}\text { Stratified } \\
\text { random }\end{array}$ & Kathangariri & Mungania & Rukuriri & Kiru & Gatunguru & Githambo & \\
\hline Management & Purposive & 5 & 5 & 5 & 5 & 5 & 5 & 30 \\
\hline Employees & $\begin{array}{l}\text { Simple } \\
\text { Random }\end{array}$ & 15 & 15 & 15 & 15 & 15 & 15 & 90 \\
\hline Tea farmers & $\begin{array}{l}\text { Simple } \\
\text { Random }\end{array}$ & 26 & 26 & 26 & 26 & 26 & 26 & 156 \\
\hline \multicolumn{2}{|c|}{$\begin{array}{l}\text { Total Respondents Per } \\
\text { Factory }\end{array}$} & 46 & 46 & 46 & 46 & 46 & 46 & \multirow[b]{2}{*}{276} \\
\hline \multicolumn{2}{|c|}{ Sample Per County } & \multicolumn{3}{|c|}{138} & \multicolumn{3}{|c|}{138} & \\
\hline
\end{tabular}

\section{RESULTS AND DISCUSSIONS}

The findings indicated that there were more female respondents than male counterparts in Embu and Murang'a counties. The findings revealed that they were $53.6 \%$ of women respondents and $46.4 \%$ of male respondents.

Table 1: Gender of the Respondents

\begin{tabular}{lcccccc}
\hline & \multicolumn{2}{c}{ Embu county } & \multicolumn{2}{c}{ Murang'a county } & \multicolumn{2}{c}{ Combined counties } \\
\cline { 2 - 7 } Gender & Frequency & \% & Frequency & \% & Frequency & \% \\
\hline Male & 64 & 46.4 & 63 & 45.7 & 128 & 46.4 \\
Female & 74 & 53.6 & 75 & 54.3 & 148 & 53.6 \\
Total & $\mathbf{1 3 8}$ & $\mathbf{1 0 0 . 0}$ & $\mathbf{1 3 8}$ & $\mathbf{1 0 0 . 0}$ & $\mathbf{2 7 6}$ & $\mathbf{1 0 0 . 0}$ \\
\hline
\end{tabular}

Generally tea crops were registered under men than women. In Murang'a county $66.7 \%$ of tea registration was under men while $33.3 \%$ was under women whereas in Embu county it was $58.7 \%$ of men against $41.3 \%$ women.

Table 2: Tea Crop Registrations

\begin{tabular}{lcccccc}
\hline & \multicolumn{2}{c}{ Embu county } & \multicolumn{2}{c}{ Murang'a county } & \multicolumn{2}{c}{ Combined counties } \\
\cline { 2 - 7 } Gender & Frequency & \% & Frequency & \% & Frequency & \% \\
\hline Male & 81 & 58.7 & 92 & 66.7 & 149 & 54.0 \\
Female & 57 & 41.3 & 46 & 33.3 & 127 & 46.0 \\
Total & $\mathbf{1 3 8}$ & $\mathbf{1 0 0 . 0}$ & $\mathbf{1 3 8}$ & $\mathbf{1 0 0 . 0}$ & $\mathbf{2 7 6}$ & $\mathbf{1 0 0 . 0}$ \\
\hline
\end{tabular}

The study established that women perform more roles in tea plantation than their male counterparts. The findings clearly indicated that the most tedious and difficult roles that might took long hours were assigned to the women. For instance plucking of tea which recorded $36.2 \%$ of women against $6.5 \%$ of men in Embu county and 19.6\% women against 15.2\% men in Murang'a county. The combined result of Embu and Murang'a counties indicated that $36.2 \%$ of women involve in tea plucking against $6.5 \%$ of men 
counterparts. Both men and women working in tea plucking was $57.2 \%$ but women constitute the majority of the workforce. Other tedious roles done by women include taking green leaves to the buying centre at $35.5 \%$ of women against $8.5 \%$ men. The findings of this study were in consistence with that of Maina et al. 2015; and Owuor et al. 2005 that, women provide most of the workforce in tea sector, however men tend to attend annual general meetings (AGMs) or any meetings at the factory or buying centre and even organized educational forums and surveys whereas women are unable attend because of numerous roles awaiting for them ranging from household chores to agricultural production. Conflicts have been also arising over the control of proceeds of tea sales as the male counterparts were more likely to receive them while women may not benefit much. This negative gender discrimination has impacted tea production negatively and results to decline in yields and neglected tea bush.

The finding further revealed that the roles that required a bit of skills application such as pruning, nursery establishment of tea plant and even land preparation were carried out by men. In Embu county for instance about $94.2 \%$ of men does pruning of tea crops and $61.6 \%$ of men does nursery establishment against $1.4 \%$ of women who carry out pruning and nursery establishment respectively while in Murang'a county $66.7 \%$ of men does pruning of tea and $21.7 \%$ of men does the nursery establishment against $3.6 \%$ of women carried out pruning and $12.4 \%$ of women who does nursery establishment respectively. These clearly showed that pruning and nursery establishment were mostly done by men in both counties and it means that men in both counties have generally failed to train women on how to carry out pruning and tea nursery establishment.

Although men and women perform different roles in tea sector, however there exist sharp divisions on who does what along gender line. Women seem to do the most involving roles in tea production as their husbands take the credit. The findings indicated that majority of women carry out tea plucking, delivery of green leaves to the buying centre and Collecting/receiving of pay slips while men counterparts were the one to go to the bank to earn bonus and monthly payments as indicated in Table 3 .

Table 3: Gender Roles in Tea Production

\begin{tabular}{|c|c|c|c|c|c|c|c|}
\hline \multirow[b]{2}{*}{$\begin{array}{l}\text { Roles played in tea } \\
\text { sector }\end{array}$} & \multirow[b]{2}{*}{ Gender } & \multicolumn{2}{|c|}{ EMBU COUNTY } & \multicolumn{2}{|c|}{$\begin{array}{c}\text { MURANG'A } \\
\text { COUNTY }\end{array}$} & \multicolumn{2}{|c|}{$\begin{array}{c}\text { COMBINED } \\
\text { COUNTIES }\end{array}$} \\
\hline & & Frequency & $\%$ & Frequency & $\%$ & Frequency & $\%$ \\
\hline \multirow{3}{*}{ Land preparation } & Male & 71 & 51.4 & 30 & 21.7 & 142 & 51.6 \\
\hline & Female & 8 & 5.8 & 23 & 16.7 & 16 & 5.8 \\
\hline & Both & 59 & 42.8 & 85 & 61.6 & 118 & 42.8 \\
\hline \multirow{3}{*}{$\begin{array}{l}\text { Nursery } \\
\text { establishment of tea } \\
\text { plant }\end{array}$} & Male & 85 & 61.6 & 30 & 21.7 & 170 & 61.6 \\
\hline & Female & 2 & 1.4 & 17 & 12.4 & 4 & 1.4 \\
\hline & Both & 51 & 37.0 & 91 & 65.9 & 102 & 37 \\
\hline \multirow{3}{*}{ Pruning of tea crop } & Male & 130 & 94.2 & 91 & 66.7 & 260 & 94.2 \\
\hline & Female & 2 & 1.4 & 5 & 3.6 & 4 & 1.4 \\
\hline & Both & 6 & 4.3 & 41 & 29.7 & 12 & 4.3 \\
\hline \multirow{3}{*}{ Plucking of tea } & Male & 9 & 6.5 & 21 & 15.2 & 18 & 6.5 \\
\hline & Female & 50 & 36.2 & 27 & 19.6 & 100 & 36.2 \\
\hline & Both & 79 & 57.2 & 86 & 62.2 & 158 & 57.2 \\
\hline \multirow{3}{*}{$\begin{array}{l}\text { Taking of green leaf } \\
\text { to buying centre }\end{array}$} & Male & 12 & 8.7 & 4 & 20.9 & 24 & 8.7 \\
\hline & Female & 48 & 35.5 & 17 & 12.3 & 98 & 35.5 \\
\hline & Both & 77 & 55.8 & 117 & 84.8 & 154 & 55.8 \\
\hline \multirow{3}{*}{$\begin{array}{l}\text { Collecting/receiving } \\
\text { of pay slips }\end{array}$} & Male & 19 & 13.8 & 6 & 4.3 & 38 & 13.8 \\
\hline & Female & 21 & 15.2 & 21 & 15.3 & 42 & 15.2 \\
\hline & Both & 98 & 71.0 & 111 & 80.4 & 196 & 71.0 \\
\hline
\end{tabular}




\begin{tabular}{llllllll}
\hline Goes to the bank to & Male & 39 & 28.3 & 87 & 63.1 & 78 & 28.3 \\
earn bonus and & Female & 28 & 20.3 & 21 & 15.2 & 56 & 20.3 \\
monthly payments & Both & 48 & 51.4 & 30 & 21.7 & 142 & 51.4 \\
\hline Attending AGMs or & Male & 71 & 51.4 & 46 & 33.3 & 142 & 51.4 \\
$\begin{array}{l}\text { any meetings at the } \\
\text { factory or buying }\end{array}$ & Female & 18 & 13.1 & 24 & 17.4 & 36 & 13.0 \\
centre & Both & 49 & 35.5 & 68 & 49.3 & 98 & 35.5 \\
\hline
\end{tabular}

The findings revealed that men access and control over the finances and fertilizers. In Embu county for instance, about $26.1 \%$ of men against $18.1 \%$ of women had access to finances and $30.4 \%$ of men against $18.1 \%$ of women had control over the finances. Whereas in Murang'a about $58 \%$ of men against $2.9 \%$ of women had access to finances and $41.3 \%$ of men against $15.2 \%$ of women control over the finances. In terms of fertilizers, about $15.9 \%$ of men against $14.5 \%$ of women in Embu county had access to fertilizers and $14.5 \%$ of men against $13.0 \%$ of women control over the fertilizers. While in Murang'a about $47.1 \%$ of men against $13.8 \%$ of women had access to fertilizers and $38.4 \%$ of men against $8.7 \%$ of women control over the fertilizers as shown in table 4.

The findings indicated that, majority of the women in Embu and Murang'a counties were discriminated along gender line in accessing and controlling over the benefits accrued from tea farming this was because majority of men were the heads of the family and therefore had power over the benefits. Women had unequal access and control over the tea benefits than their men counterparts. It appeared that men controlled all the women's productive benefits even though they did not work for those benefits. In the case where the women were single, widow or divorced/separated and own their land either through buying or inherit from their parents or husbands after death, thus heading the households and were able to access and control over family resources including the all benefits accrued from tea farming this is because they had rightfully acquired the tea owners' rights. The findings of this study concur with that of FAO, (2009) that women are permitted to access and control over the resources such as land and other benefits either directly or indirectly, as the majority have limited or no access to or control over land. According to Yemisi \& Idisi, (2014), women in most African countries rarely inherit land in their own right, particularly in patrilineal community but instead its men who are the heads of household are allocated the land. On the other hand, women in matrilineal communities are allocated land in their own right; however the land is still under the control of male clan heads or their husbands (FAO, 2009).

The results clearly demonstrated that, majority of men in both counties under study were able to access to and control over the finances and fertilizers, however women were seen to access and control over the commodities that were being used in kitchen such as processed tea leaves. The findings of this study was in agreement with that of Kibere et al; (2013) that, there was discrimination in gender role in tea production and in access to and control over the benefits accrued from it. He further observed that although women do much in tea sector they couldn't access and control over the tea benefits except through their fathers, husbands or if they were widowed. It also agree with that of (Mohammed \& Abdulquadri, 2012). That, in terms of access to agricultural inputs, information technology and financial, women have more challenges than their male counterparts. Some agricultural crops are even categorized as man's crop whereas others are considered as woman's crop which has negatively affected the food production. 
Table 4: Access to and Control over the Benefits Accrued from Tea Farming

\begin{tabular}{llcccc}
\hline \multirow{2}{*}{ Benefits accrued from tea } & \multicolumn{2}{c}{ Embu county } & \multicolumn{2}{c}{ Murang'a county } \\
\cline { 2 - 6 } Access to fertilizers & Gender & Frequency & \% & Frequency & \% \\
& Male & 22 & 15.9 & 65 & 47.1 \\
& Female & 20 & 14.5 & 19 & 13.8 \\
& Both & 96 & 69.6 & 54 & 39.1 \\
\hline Access to finances & Male & 36 & 26.1 & 80 & 58.0 \\
& Female & 25 & 18.1 & 4 & 2.9 \\
& Both & 77 & 55.8 & 54 & 39.1 \\
\hline Access to processed tea leaves & Male & 21 & 15.2 & 82 & 59.4 \\
& Female & 35 & 25.4 & 9 & 6.5 \\
& Both & 82 & 59.4 & 47 & 34.1 \\
\hline Control over fertilizers & Male & 20 & 14.5 & 53 & 38.4 \\
& Female & 18 & 13.0 & 12 & 8.7 \\
& Both & 96 & 69.6 & 71 & 51.4 \\
\hline Control over finances & Male & 42 & 30.4 & 57 & 41.3 \\
& Female & 25 & 18.1 & 21 & 15.2 \\
& Both & 67 & 48.6 & 60 & 43.5 \\
\hline Control over processed tea leaves & Male & 14 & 10.1 & 42 & 30.4 \\
& Female & 55 & 39.9 & 23 & 16.7 \\
& Both & 65 & 47.1 & 73 & 52.9 \\
\hline
\end{tabular}

\section{CONCLUSIONS AND RECOMMENDATIONS}

It is evident from the study findings that there exists gender discrimination in terms of roles played in tea production and accessing to and control over the proceeds from tea sales. The findings revealed that women's involvement in tea production is more intense that men counterparts however, they could not access and control over the tea benefits except through their husbands, parents or if they were widowed. The study came to a conclusion that men household heads need to consider women counterparts as equal partners in accessing and control over the benefits accrued from tea farming. This study recommends that Kenya tea development agency to increase its sensitization forums and conducts regular workshops to educate the tea growers on gender equality in regards to distribution of proceeds from tea sales, access to and control over tea benefits. This could not only help to empower and motivate women but also demystify the gender stereotypes that men have about women and therefore eliminate gender discrimination in tea growing communities.

\section{REFERENCES}

1. African Union. 2003. Protocol on the Rights of Women in Africa. Retrieved fromhttp://www.equalitynow.org/campaigns/africaprotocol/2010 on November 2016.

2. Food Organization Agency, corporate document repository (2009). The rights of self-employed rural women. Available from: http://www. fao.org/docrep/005/y4311e/y4311e06.htm (Accessed: 08 January 2017).

3. ILO. (2002). Women and Men in the Formal Sector: A Statistical Picture. Geneva. ILO

4. Kibere E. N, KimanE. N. \& Lodiaga J. M. (2013) .Gender dynamics in the access and control of benefitsaccrued from tea farming in Kiganjo division, Gatundu district. 1 (1), 2013: 6-10

5. KIPPRA Policy Paper No. 1. Nairobi, Kenya.

6. Kothari, C. R. (2004): Research Methodology, Methods and Techniques: 4th edition,Wiley Eastern Ltd. 
7. Maina, F.N.W.; Mathenge, P.W.; Mwathe, Z.M. \& Mathenge, M.M. (2015). Challenges facing the tea Sector in Nyeri County Proceedings of the First International Conference on Tea Science and Development pp46-52.

8. Mohammed, B. T. \& Abdulquadri, A. F. (2012). Comparative analysis of gender involvement in agricultural production in Nigeria Vol. 4(8), pp. 240-244.

9. Mwaura F.\& Muku O.(2007) Tea Farming Enterprise Contribution to Smallholders' Well Being in Kenya Conference Proceedings (2007) 307-313

10. Nyangito HO (2001). Policy and Legal Framework for the Tea Sub-sector and the Impact of Liberalization in Kenya: Kenya Institute of Public Policy Research and Analysis (KIPPRA),

11. UNDP. (2001). Engendering Development: Through Gender Equality, Results, Resources and Voice. A World Bank Policy Research Report. WashingtonD.C.

12. UNDP/IMF(2007) Gender and Economic Growth.Retrieved on November 2016 from worldbank.org/gender report/ 2010. University Press

13. World Bank,(2001). Engendering Development. Oxford University Press

14. Yemisi G M \& Idisi P D. (2014). Gender inequality and women participation in agricultural development in Nigeria Vol. 2(11) 2014, pp. 296-301. 